\title{
ARTICLE
}

\section{Influence of Thermal Treatment on Kankara Kaolinite}

\author{
Lawrence C Edomwonyi-Otu*, Benjamin Olufemi Aderemi ${ }^{\dagger}$, \\ Abdulkarim Salawudeen Ahmed ${ }^{\dagger}$, Neil J Coville**, Malik Maaza ${ }^{\dagger \dagger}$
}

In this work, the influence of thermal treatment on the structure of Kankara kaolinite was studied for the first time, using X-ray diffractogram (XRD), EDX, NanoSEM, FTIR-Attenuated Total Reflectance, DTA/TGA and BET surface area measurements. The treatment applied by temperatures represents the peak of the transformation stages. The results show that surface area decreases with increase in temperature of treatment, while its crystal structure was transformed from the native kaolinite structure via the amorphous metakaolin to the typical mullite/crystobalite structure, although with some unidentifiable peaks. The morphological studies showed that Kankara kaolinite is composed of nano-platelets of about 30nm thickness and in bundles of $1-3 \mu \mathrm{m}$ thicknesses with some marked variations/reductions as the treatment temperatures increases. The DTA/TGA result shows that the kaolinite undergoes dehydroxylation at $528.56^{\circ} \mathrm{C}$ while being converted to metakaolin with a weight loss of about $14.4 \%$. The presence of the characteristic $\mathrm{OH}, \mathrm{Al}-\mathrm{OH}, \mathrm{Si}-\mathrm{OH}$ and $\mathrm{Si}-\mathrm{O}-\mathrm{Al}$ bands were confirmed with the ATR studies, which also showed the disappearance and subsequent appearance of new bands as the treatment temperature increased. This also affected the surface area and pore sizes of the transformation products.

\section{Introduction}

The drive to increase our Gross Domestic Product (GDP) as a nation along the mandate of the vision 20-2020 coupled with the development and application of our natural mineral resources has led to the

\footnotetext{
* Chemical Engineering Department, UCL and Ahmadu Bello University, Nigeria, uceclce@ucl.ac.uk

† Ahmadu Bello University, Nigeria, efemdor@yahoo.com, asahmed@abu.edu.ng

** School of Chemistry, University of the Witswatersrand, South Africa, neil.coville@ wits.ac.uk

†'Nanosciences Laboratory, Materials Research Department, iThemba Laboratories, South Africa,maaza@tlabs.ac.uk
}

intensification of research efforts with the aim of adding value to otherwise valueless vast mineral deposits in Nigeria. One such mineral that has received attention is kaolinite, with deposits estimated at over 3 billion metric tons according to the Raw Materials Research and Development Council (RMRDC) and the Ministry of Solid Minerals Development (2003).

Kaolinites and more specifically Kankara kaolinites have been found to be of immense application in alum and alumina production, ceramics, zeolite catalysts, adsorbents for heavy metals and currently in catalysis, to mention a few (Ahmed 1986, Aderemi and Oludipe 2000, Aderemi et al. 2001, Edomwonyi-Otu and Aderemi 2009, Edomwonyi-Otu, 


\begin{tabular}{|l|c|c|c|c|c|c|c|c|c|}
\hline SAMPLES & $\mathbf{S i O}_{\mathbf{2}}$ & $\mathbf{A l}_{\mathbf{2}} \mathbf{O}_{\mathbf{3}}$ & $\mathbf{C a O}$ & $\mathbf{F e}_{\mathbf{2}} \mathbf{O}_{\mathbf{3}}$ & $\mathbf{M g O}$ & $\mathbf{K}_{\mathbf{2}} \mathbf{O}$ & $\mathbf{N a}_{\mathbf{2}} \mathbf{O}$ & $\mathbf{T i O}_{\mathbf{2}}$ & $\begin{array}{c}\mathbf{S i O}_{\mathbf{2}} \mathbf{} \\
\mathbf{A l}_{\mathbf{2}} \mathbf{O}_{\mathbf{3}}\end{array}$ \\
\hline Raw & 45.10 & 33.41 & 0.343 & 0.555 & 1.49 & 0.693 & 0.016 & 0.100 & 2.295 \\
\hline Beneficiated & 47.48 & 36.80 & 0.325 & 0.562 & 1.27 & 0.544 & 0.050 & 0.066 & 2.179 \\
\hline Metakaolin & 49.40 & 41.56 & 0.289 & 0.483 & 1.12 & 0.427 & 0.038 & 0.067 & 2.0203 \\
\hline
\end{tabular}

Table 1: Elemental composition of raw and calcined $\left(750^{\circ} \mathrm{C}\right)$ Kankara kaolinite

\begin{tabular}{|l|l|c|c|c|c|}
\hline Sample & $\begin{array}{l}\text { Temp of } \\
\text { preparation }\end{array}$ & $\begin{array}{c}\text { Time of prepa- } \\
\text { ration }(\mathbf{m i n})\end{array}$ & $\begin{array}{c}\text { BET surface } \\
\text { area } \mathbf{( m 2 / g )}\end{array}$ & $\begin{array}{c}\text { Pore volume } \\
\mathbf{( c m} \mathbf{m} / \mathbf{g})\end{array}$ & $\begin{array}{c}\text { Pore size } \\
\mathbf{( n m})\end{array}$ \\
\hline KAOLIN & Room temp & & 8.5403 & 0.054601 & 25.57349 \\
\hline KAOLIN & $750^{\circ} \mathrm{C}$ & 240 & 9.1217 & 0.059222 & 25.96991 \\
\hline KAOLIN & $1050^{\circ} \mathrm{C}$ & 240 & 4.5762 & 0.040291 & 35.21816 \\
\hline
\end{tabular}

Table 2: BET measurement of Kankara kaolinite at room temperature, $750^{\circ} \mathrm{C}$ and $1050^{\circ} \mathrm{C}$

Aderemi and Ahmed 2010, Edomwonyi-Otu, Aderemi and Ofuko 2010). Most of these processes involve the thermal treatment of the kaolinite which leads to a transformation of its structures with the removal of the bonded water, but there has not been a concerted effort to look in detail at the effect of this thermal treatment on the kaolinite, a gap this current paper strives to fill. An understanding of these will enable a proper and more specific application of these materials with the resultant increase in its value and sustainability.

\section{Experimentation}

Raw Kankara kaolin was subjected to varying thermal treatments at temperatures ranging from $400^{\circ} \mathrm{C}$ to $1050^{\circ} \mathrm{C}$, while the samples obtained from each stage of treatment were analyzed to determine their surface area, pore volume and radii, microstructure and morphology, elemental composition, crystallographic structure, bond spectrum, thermograph etc with the help of BET surface area analyzer (Micromeritis, Tristar 3000), Energy Dispersive X-ray Fluorescence Machine (EDXRF, PANalytical XRA 1160), scanning electron microscopy (Nova NanoSEM 230), X-ray diffractometry (XRD) in a $\theta-2 \theta$ mode with CuKa 1 (AXS Bruker, $\lambda=1.54056 \AA ̉$ ), FTIR-
ATR spectroscopy via Perkin Elmer Spectrum 1000 FT-IR Spectrometer, and Perkin Elmer DSC 100 respectively.

\section{Results and Discussion}

Table 1 shows the result of the elemental analysis of the kaolinite from the raw to a temperature of $750^{\circ} \mathrm{C}$ (metakaolin). It can be observed that while other oxides had insignificant changes, there was a $24.4 \%$ increase in the alumina $\left(\mathrm{Al}_{2} \mathrm{O}_{3}\right)$ content with a corresponding $9.53 \%$ increase in the silica $\left(\mathrm{SiO}_{2}\right)$ content; a development that improves its quality and makes it suitable for high grade

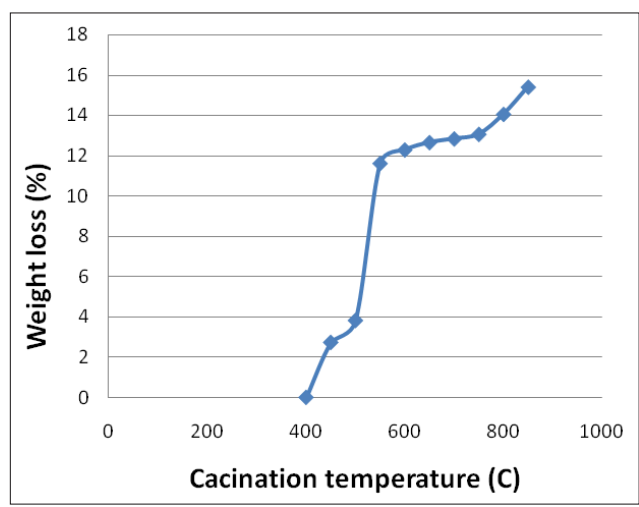

Figure 1: Effect of calcination temperature on weight loss for Kankara (white) kaolinite 
alum production, having attained a 2:1 silica-alumina ratio (Kirk and Othmer 1997, Edomwonyi-Otu, Aderemi and Ahmed 2010). There were no marked differences observed at higher temperatures since the material has already attained thermal stability in terms of its composition. This final composition also makes it a cement additive with a good pozzolanic property (Ilić, Mitrović, and Miličić 2010).

Table 2 shows the result of the BET analysis of samples treated at $750^{\circ} \mathrm{C}$ and $1050^{\circ} \mathrm{C}$, which represent the boundaries of transformation. It can be observed that as the temperature increased there was a corresponding increase in the surface area, pore volume and size at $750^{\circ} \mathrm{C}$, which can be attributed to the elimination of combustible impurities within the pores of the kaolinite, thereby increasing accessibility within it as also attested to by the result of the elemental analysis (Table 1 referred). At a temperature of $1050^{\circ} \mathrm{C}$ there was a rather sharp decrease in both the surface area and pore volume with a corresponding increase in the pore size, which can be attributed to the fact that as temperature increased the pore size increased with a subsequent collapse of the walls of the pores, leading to limited access within the material. The low pore volume and high pore size could imply that the pores are developed only close to the surface of the material, a characteristic of its transformation to a crystalline structure from its amorphous structure at $750^{\circ} \mathrm{C}$ as confirmed by the diffractogram.

Figure 1 shows the weight loss associated with thermal treatment of Kankara kaolinite up to $850^{\circ} \mathrm{C}$. It can be observed that the remarkable loss occurred between $500^{\circ} \mathrm{C}$ and $600^{\circ} \mathrm{C}$ and stabilized at about $750^{\circ} \mathrm{C}$ which corresponds to a transformation of phase from the crystalline kaolinite to the amorphous metakaolin. This observation is corroborated by figure $\mathbf{2}$ which showed the result of the DTA/TGA analysis where dehydroxylation of Kankara kaolinite is seen at $528.56^{\circ} \mathrm{C}$ corresponding to a weight loss of

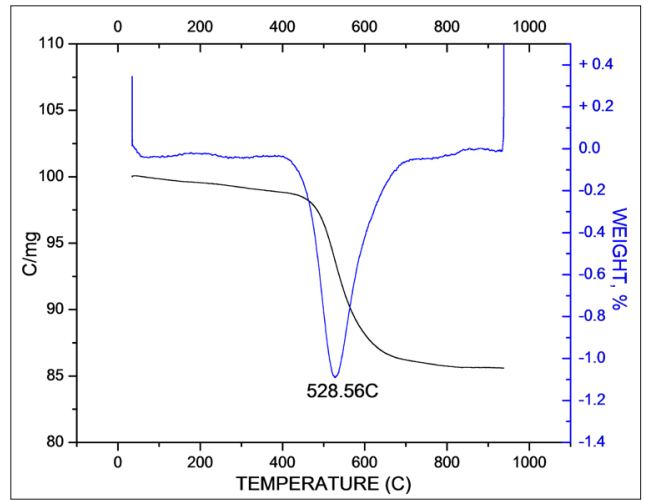

Figure 2: DTA and TGA results for Kankara kaolinite

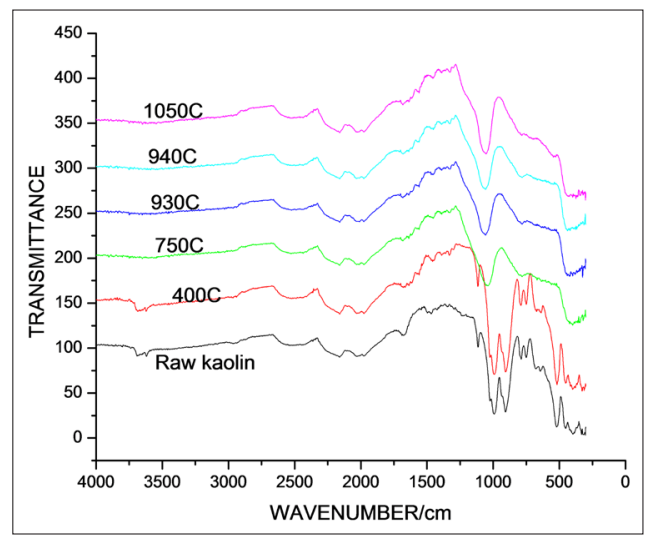

Figure 3: FTIR-ATR of Kankara kaolinite showing the bands present and their disappearance as temperature of treatment increases from $400^{\circ} \mathrm{C}$ to $1050^{\circ} \mathrm{C}$

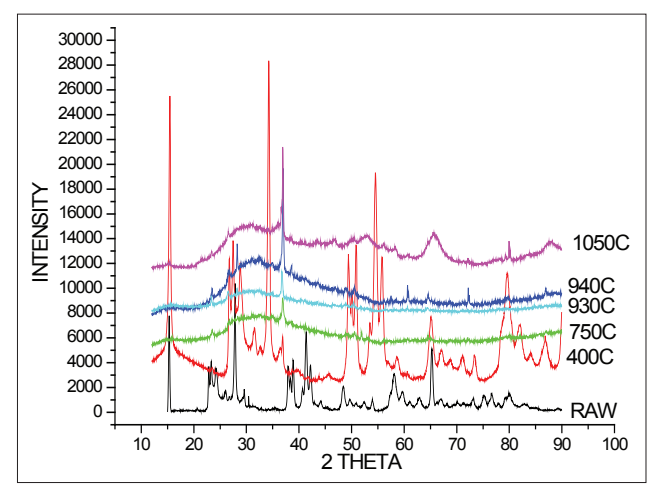

Figure 4: X-ray Diffractogram of Kankara kaolinite showing the crystallographic transformation as temperature of treatment increases from $400^{\circ} \mathrm{C}$ to $1050^{\circ} \mathrm{C}$ 


\begin{tabular}{|c|c|c|c|}
\hline $\begin{array}{l}2 \mathrm{Al}_{2} \mathrm{Si}_{2} \mathrm{O}_{5}(\mathrm{OH})_{4} \\
\text { Kaolin }\end{array}$ & $500-850^{\circ} \mathrm{C}$ & $\begin{array}{l}2 \mathrm{Al}_{2} \mathrm{Si}_{2} \mathrm{O}_{7}+4 \mathrm{H}_{2} \mathrm{O} \\
\text { Metakaolin }\end{array}$ & 1 \\
\hline $\begin{array}{l}2 \mathrm{Al}_{2} \mathrm{Si}_{2} \mathrm{O}_{7} \\
\text { Metakaolin }\end{array}$ & $900-950^{\circ} \mathrm{C}$ & $\begin{array}{l}\mathrm{Si}_{3} \mathrm{Al}_{4} \mathrm{O}_{12}+\mathrm{SiO}_{2} \\
\text { Spinel }\end{array}$ & 2 \\
\hline $\begin{array}{l}3 \mathrm{Si}_{3} \mathrm{Al}_{4} \mathrm{O}_{12} \\
\text { Spinel }\end{array}$ & $1050^{\circ} \mathrm{C}$ & $\begin{array}{l}2 \mathrm{Si}_{2} \mathrm{Al}_{6} \mathrm{O}_{13}+5 \mathrm{SiO}_{2} \\
\text { Mulite Crystobalite }\end{array}$ & 3 \\
\hline
\end{tabular}

Figure 5: Thermal transformation equations for Kankara kaolinite

about $14.4 \%$ in agreement with literature expectations (Kirk and Othmer 1997, De Mejía et al. 2008, Edomwonyi-Otu, Aderemi and Ofuko 2010).

In Figure 3 it can be observed that as the temperature of treatment increases there is a disappearance of some bands between wavenumbers 1000 and 250. This region corresponds majorly to the $\mathrm{O}-\mathrm{H}-\mathrm{O}$ frequency bands which are broken as a result of the increased kinetic energy of the atoms as temperature increases.

The material is observed to become stable in terms of band stability with temperatures from $750^{\circ} \mathrm{C}$ which corresponds to its transformation to metakaolin and complete dehydroxylation of the material as seen also in figures 2 and 3. Other bands present in the raw kaolinite include impurities from combustible carbonaceous materials, nitrates and carbonates. In figure $\mathbf{4}$ the transformation from the crystalline kaolinite to the amorphous metakaolin $\left(750^{\circ} \mathrm{C}\right)$ can be observed with a quartz peak at about $37^{\circ}$ which obviously is an impurity. The diffractogram for the raw and at $400^{\circ} \mathrm{C}$ are typical for kaolinite materials, though with slight differences which may be due to impurities arising from the geological locations and formations. As temperatures increase from $750^{\circ} \mathrm{C}$ to $1050^{\circ} \mathrm{C}$ more quartz and silica-related peaks are observed to emerge, which are evidence of transformation of the material as confirmed by the transformation equations in figure $\mathbf{5}$ (Bellotto et al. 1995, Grim 1953).

It is worth noting that some of peaks in the $940^{\circ} \mathrm{C}$ and $1050^{\circ} \mathrm{C}$ diffractogram could not be identified owing to the absence of this mineral deposit in the crystallographic databases used by the XRD machine for peak matching. The reactivity of this material is also known to be enhanced as it converts from the crystalline kaolinite to the reactive amorphous metakaolin, which is easily dealuminated by inorganic acids such as sulfuric acid to yield alums and can also be used as additives in cements because it has appreciable pozzolanic properties. Its thermal stability makes it suitable for high applications in ceramics (Ahmed 1986, Murat and Driouche 1998, Aderemi and Oludipe 2000, Aderemi, Edomwonyi-Otu and Adefila 2009, Edomwonyi-Otu and Aderemi 2009, Wang et al. 2010).

\section{Conclusions}

1. Kankara kaolinite undergoes dehydroxylation to form metakaolin at $528.86^{\circ} \mathrm{C}$.

2. The surface area increases with temperature until amorphous phase is obtained and then decreases with further increase in temperature of treatment.

3. The loss in weight increases with temperature, agreeing with the literature's expectations for kaolinites.

4. Kankara kaolinites undergo crystallographic changes with increases in temperature, resulting in some unique and unidentifiable peaks.

\section{Acknowledgement}

This work was part funded by a fellowship from NanoSciences African Network (NANOAFNET). 


\section{References}

Aderemi, B O, Edomwonyi-Otu, L C, and Adefila, S S 2009 A New Approach to Metakaolin Dealumination. Australian Journal of Basic and Applied Sciences, 3(3): 2243-2248.

Aderemi, B O, Oloro, E F, Joseph, D, and Oludipe, J 2001 Kinetics of the Dealumination of Kankara Kaolin Clay. Nigerian Journal of Engineering, 9(1): 40-44.

Aderemi, B O, and Oludipe, J O 2000 Nigerian Journal of Engineering, 2(8): 22-30.

Ahmed, K S, 1986 Development of Phosphate Bonded Fireclay Refractory. MSc. Ahmadu Bello University, Zaria, Nigeria.

Bellotto, M, Gualtieri, A, Artioli, G, and Clark, S M 1995 Kinetic Study of the Kaolinite-Mullite Reaction Sequence. Part I: Kaolinite Dehydroxylation. Phys. Chem. Minerals, 22: 207-214.

Edomwonyi-Otu, L C, and Aderemi, B O 2009 Alums from Kankara kaolin. Journal of Research in Engineering 6(1): 105-111.

Edomwonyi-Otu, L C, Aderemi B O, and Ahmed, K S 2010 Effect of Beneficiation on the Yield and Quality of Alum from Kankara Kaolin. Nigerian Journal of Engineering, 16(2): 36-43.
Edomwonyi-Otu, L C, Aderemi, B O, and Ofoku, A G 2010 The Effect of Kaolin Calcination Temperature and Dealumination Time on Alum Yield from Kankara Kaolin. African Journal of Natural Sciences, 13: 69-74.

Grim, R E 1953 Clay Mineralogy. New York: McGraw-Hill, pp. 46, 212.

Ilić, B R, Mitrović, A A, and Miličić, L J R 2010 Thermal Treatment of Kaolin Clay. Hem. Ind. 64(4): 351-356.

Kirk, R E, and Othmer, F 1997 Kirk-Othmer Encyclopedia of Chemical Technology. Volume 2. New York: Wiley Interscience, pp. 219-268.

Mejía de Gutiérrez, R, Torres, J, Vizcayno, C, and Castello, R 2008 Influence of the Calcination Temperature of Kaolin on the Mechanical Properties of Mortars and Concretes Containing Metakaolin. Clay Minerals, 43(2): 177-183.

Murat, M, and Driouche, M 1988 Chemical Reactivity of Thermally Activated Clay Minerals. Cement Concrete Research, 18: 221-228.

Wang, M R, Jia, D C, He, P G, and Zhou, Y 2010 Influence of Calcination Temperature of Kaolin on the Structure and Properties of Final Geopolymer. Materials Letters, 64: 2551-2554.

\footnotetext{
How to cite this article: Edomwonyi-Otu, L, et al. 2013 Influence of Thermal Treatment on Kankara Kaolinite. Opticon1826, 15: 5, pp. 1-5, DOI: http://dx.doi.org/10.5334/opt.bc

Published: 25 March 2013

Copyright: (c) 2013 The Author(s). This is an open-access article distributed under the terms of the Creative Commons Attribution 3.0 Unported License (CC-BY 3.0), which permits unrestricted use, distribution, and reproduction in any medium, provided the original author and source are credited. See http://creativecommons.org/licenses/by/3.0/.
}

] $\mathbf{u}[$ Opticon1826 is a peer-reviewed open access journal published by Ubiquity Press 